\title{
USP17L2 Gene
}

National Cancer Institute

\section{Source}

National Cancer Institute. USP17L2 Gene. NCI Thesaurus. Code C120054.

This gene plays a role in the deubiquitination of protein substrates. 